\title{
Performance of gasoline fuel cell cars - a simulation study
}

\author{
K Fischer $^{1}$, M Rzepka ${ }^{1}$, U Stimming ${ }^{1,3}$, J-W Biermann ${ }^{2}$, M Johannaber $^{2 *}$, and H Wallentowitz ${ }^{2}$ \\ ${ }^{1}$ Bavarian Centre for Applied Energy Research, Garching, Germany \\ ${ }^{2}$ Institute for Automotive Engineering, RWTH Aachen, Aachen, Germany \\ ${ }^{3}$ Department of Physics, Technical University Munich, Garching, Germany
}

The manuscript was received on 29 March 2004 and was accepted after revision for publication on 13 January 2005.

DOI: $10.1243 / 095440705 X 11068$

\begin{abstract}
This paper reports on the analysis and evaluation of different automobile traction concepts of an electrically powered compact class vehicle equipped with an energy converting fuel cell system. All simulation models of the fuel cell cars are based on an on-board gasoline reformer unit. As fuel cell systems both a solid oxide fuel cell (SOFC) and a polymer electrolyte membrane fuel cell (PEMFC) are compared. For a study of the influence of the energy management concept on system performance, the fuel cell car is eventually equipped with an auxiliary energy buffering battery. A variety of studies are shown concerning the performance and energy consumption of the different systems as well as sensitivity studies for selected system parameters.
\end{abstract}

Keywords: fuel cells, simulation, reformer, polymer electrolyte membrane (PEM), solid oxide fuel cell (SOFC)

\section{INTRODUCTION}

Fuel cell cars may become a viable alternative to today's conventional cars equipped with a diesel or gasoline combustion engine. Most of the large car manufacturers have already presented demonstration models of fuel cell cars, which are mostly equipped with pure hydrogen storage systems or methanol reforming units. But for these two fuels no distribution infrastructure exists. Therefore, when considering fuel infrastructure one alternative is the use of conventional fuels like gasoline or diesel [1].

Like methanol, these fuels can be reformed on board, however at elevated temperatures (approx. $800^{\circ} \mathrm{C}$ ) with a reformate of high CO content (around 10-12 per cent). Since further cleaning to fulfil the requirements of a PEMFC (polymer electrolyte membrane fuel cell) system is cumbersome and inefficient, the use of a solid oxide fuel cell (SOFC) stack instead of a PEM stack is an alternative, as the SOFC is also operated at high temperatures and can convert CO electrochemically.

\footnotetext{
* Corresponding author: Institute for Automotive Engineering, Aachen University of Technology, Steinbachstrasse No 7, 52074 Aachen, Germany.email: johannaber@ika.rwth-aachen.de
}

The intention of the presented study was to compare an SOFC to a PEMFC system on the basis of gasoline, regarding their performance and energy consumption for driving a passenger car. As for a given driving cycle the load requirements to the fuel cell system may frequently change, also the partial load characteristics of the analysed systems may strongly influence the overall system behaviour. An additional battery avoids load peaks and thus makes it possible to use smaller and thus less expensive fuel cell systems. This study examines both a pure fuel cell vehicle (equipped only with a small buffer battery) and a hybrid vehicle with a large battery.

In the pure fuel cell vehicle the fuel cell power output has to follow almost directly the changing power demand given by the velocity profile of the used driving cycle. In the second (hybrid) concept the fuel cell system mainly provides a more or less constant base load while the power peaks are taken from the battery controlled by the energy management system. During periods of low power demand the battery is recharged. Moreover, a battery provides the capacity for the recuperation of brake energy. However, a large battery may also increase fuel consumption by the additional battery mass and battery losses due to the charging and discharging currents. 
As both the fuel cell system and the battery efficiency vary with electrical load the integrated system efficiency strongly depends on the power demand distribution and therefore on the applied driving cycle. A hybridized system consisting of a fuel cell system and a battery, both able to deliver power to propel the vehicle, gives numerous possibilities for the strategy of the energy management and the sizing of the components. Numerical simulations are thus a powerful means to assess the overall performance of different system architectures, to investigate different system layouts, and to find the best solution to meet the prerequisites for a special application.

The simulation models introduced in this paper were developed in a cooperation between the Institute for Automotive Engineering of the University of Aachen (responsible for the set-up of the mechanical and electrical part of the powertrain) and the Bavarian Center of Applied Energy Research, responsible for the fuel cell systems. The simulation model was built with the Matalb/SIMULINK system design tool [2]. Details of the simulation code are described in reference [3]. This paper gives a short summary and presents some of the main results.

\section{FUEL CELL SYSTEM}

As discussed above as an alternative to using PEMFC, when a hydrogen distributing infrastructure is in place, fuel cell cars may also use the existing gasoline/diesel fuel infrastructure. Therefore this study concentrates on the simulation and analysis of fuel cell cars equipped with a gasoline reformer unit. As an example, Fig. 1 shows the main components of a PEM fuel cell system. Technical details of the implementation into the simulation model are described in reference $[\mathbf{3}]$.

Both the SOFC and the PEMFC system are equipped with an autothermal gasoline reformer unit combining POX (partial oxidation - exothermal) and steam (endothermal) reforming processes. The latter has been chosen as steam reforming is considerably more efficient than POX, thus increasing total system efficiency compared with a system equipped only with a POX reformer. Naturally, compared with a pure POX system, the water for the steam reforming process has to be provided by an additional onboard water storage tank. Consequently the system complexity and refuelling effort are increased.

The reformer operating temperature is held at about $720^{\circ} \mathrm{C}$ by a control unit adjusting the amount of water injected in the reformer unit compared with the amount of air if the actual temperature is below
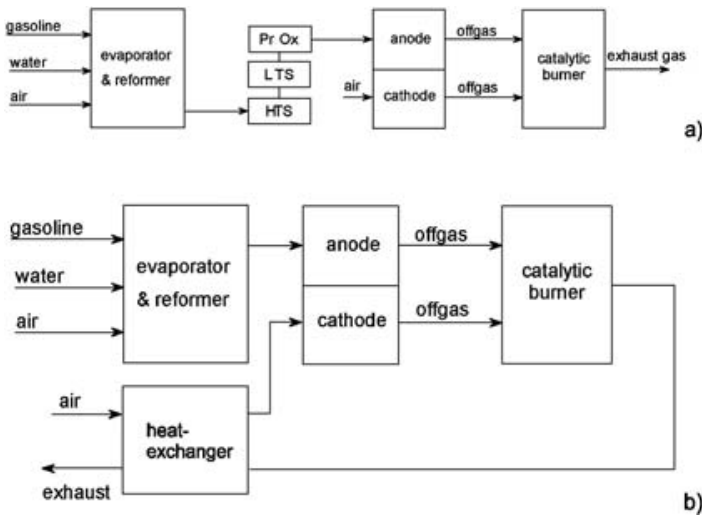

Fig. 1 (a) Components and layout of the analysed PEMFC system. The CO content of the reformate is reduced to $<10 \mathrm{ppm}$ by the high- and lowtemperature shift reactors (HTS, LTS) and the preferential oxidation unit (PrOX). (b) Components and layout of the analysed SOFC system

or above its nominal value. As steam reforming is more efficient than POX reforming, this 'steam-toair-ratio' directly influences the reformer efficiency. As a consequence a change in the thermal integration of the reformer unit also directly influences the efficiency of the whole system, which has been analysed in detail below.

As typical values in the simulations the power specific mass for the total fuel cell system was set to $5.5 \mathrm{~kg} / \mathrm{kW}$ for the SOFC system and to $8.0 \mathrm{~kg} / \mathrm{kW}$ for the PEMFC system. This is because the higher complexity of the PEMFC system offsets the lower mass of the PEMFC stack versus the SOFC stack. The calculated values were multiplied by a factor of two, resulting in the above values, in order to provide a rather conservative basis for the calculation.

The nominal temperatures for the SOFC and the PEMFC stacks are set to $840^{\circ} \mathrm{C}$ and $110^{\circ} \mathrm{C}$, respectively. During operation the fuel cell stacks are heated by internal losses, they therefore have to be cooled actively to keep them at their operational temperature. The PEMFC stack is operated at a constant cathode air excess of $\lambda=1.5$ and cooled by an additional water circuit. The SOFC stack is cooled by the air flow on the cathode side. To avoid thermal stress the temperature difference between air inlet and stack bulk temperature is limited to $100 \mathrm{~K}$. Therefore the varying cooling demand is mainly accounted for by adjusting the cathode air flow. This gives values for the air excess between $\lambda=8$ and 20, depending on the operating conditions. Hence the electrical power demand for external blowers for the SOFC is larger compared with the PEMFC system. 
As a first result Fig. 2 shows the total system efficiency of the two fuel cell systems as a function of its nominal power (defined as the power output at $750 \mathrm{mV}$ single-cell voltage). The mean system efficiency is defined as the total electric energy output of the system in a given driving cycle compared with the upper heating value of the total fuel input. It is influenced by the reforming efficiency, stack electric efficiency, efficiency of auxiliary gas cleaning components, fuel utilization in the stack, and the electric power demand of blowers and pumps.

As can be seen, due to the enhanced partial load operation for larger stacks the system efficiency increases with increasing nominal power. This effect is more pronounced for the SOFC system as a consequence of the different partial load characteristics of PEMFC and SOFC [3].

\section{BATTERY AND ENERGY MANAGEMENT}

The battery model in the simulation is based on a nickel metal hydride battery (NiMH) that is used, for example, in the Toyota Prius [4], [5], and the Honda Insight [6]. Additional data from the ADVISOR simulation tool [7] were used for the calculation of internal ohmic resistances.

Table 1 shows the specifications of the two battery sizes that were used in the two different traction concepts. In the pure fuel cell car the energy

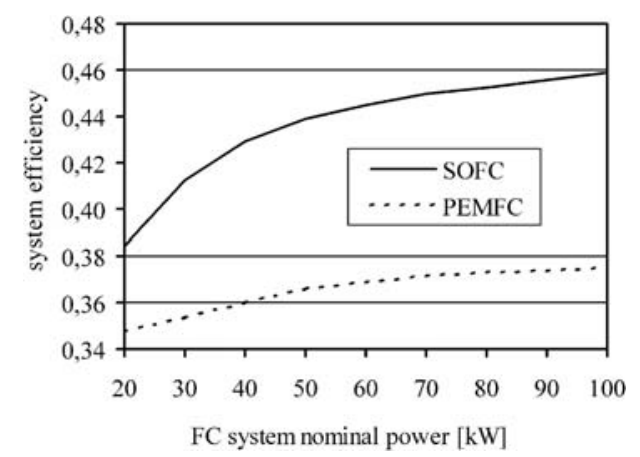

Fig. 2 System efficiency of PEMFC and SOFC system as function of the nominal power (defined as the power output at $750 \mathrm{mV}$ single-cell voltage) in the NEDC

Table 1 Used parameters in the battery model

\begin{tabular}{lll}
\hline & Small battery & Large battery \\
\hline Cells & 240 & 720 \\
Cell voltage & $1.2 \mathrm{~V}$ & $1.2 \mathrm{~V}$ \\
Capacity & $6.5 \mathrm{Ah}$ & $19.5 \mathrm{Ah}$ \\
Weight & $40 \mathrm{~kg}$ & $120 \mathrm{~kg}$ \\
\hline
\end{tabular}

management unit passes, more or less directly, the power demand of the car to the fuel cell system. An additional small battery is used for storing recuperative energy and for an additional power supply for time periods with load gradients larger than the response time of the fuel cell system, which was set to $100 \mathrm{~ms}$.

In the hybrid concept the power demand to the fuel cell system is calculated by the energy management unit as an average value of the power demand over the last $60 \mathrm{~s}$. This leads to a more or less constant base load, which is delivered by the fuel cell system while the battery serves to provide the short power peaks and is reloaded in time periods with low power demand. In addition, the state of charge (SOC) of the battery is controlled by the energy management, which increases the power request to the fuel cell system, if the SOC is low, and reduces it when the SOC is above the target value of 0.8 . This ensures enough capacity for energy recuperation as well as a high load-reload battery efficiency.

\section{DRIVE TRAIN AND DRIVING CYCLES}

In addition to modelling the fuel cell system, the whole car and drive train were also simulated. The model accounts, for example, for car mass, all driving resistances, friction losses, and electric motor efficiency. These modules permit an accurate calculation of the actual electrical energy demand during a given driving cycle. Typical vehicle parameters were taken from a Mercedes-Benz A-class - a common compact class vehicle. Details can be found in reference [3]. The weight of the car (without fuel cell system) was set to $1150 \mathrm{~kg}$.

Due to their clean energy conversion and the possibility of the recuperation of brake energy, one possibility is to use fuel cell vehicles in urban traffic. Thus, two driving cycles were studied as shown in Fig. 3, the new European driving cycle (NEDC) and a cycle that was measured in the city traffic of Aachen, Germany (Aachen City). The latter cycle is only $390 \mathrm{~s}$ long, i.e. only one third of the NEDC.

The NEDC [Fig. 3(a)] is a standard synthetic cycle consisting of an urban part with velocities up to $50 \mathrm{~km} / \mathrm{h}$ and a short highway part with a maximum velocity of $120 \mathrm{~km} / \mathrm{h}$. The maximum acceleration in this cycle is $1.04 \mathrm{~m} / \mathrm{s}^{2}$ and the average speed is $33.2 \mathrm{~km} / \mathrm{h}$.

The measured Aachen City cycle [Fig. 3(b)] consists only of an urban part with velocities of up to $45 \mathrm{~km} / \mathrm{h}$, but it has higher accelerations up to $2.2 \mathrm{~m} / \mathrm{s}^{2}$. Its average speed is $12.9 \mathrm{~km} / \mathrm{h}$. 


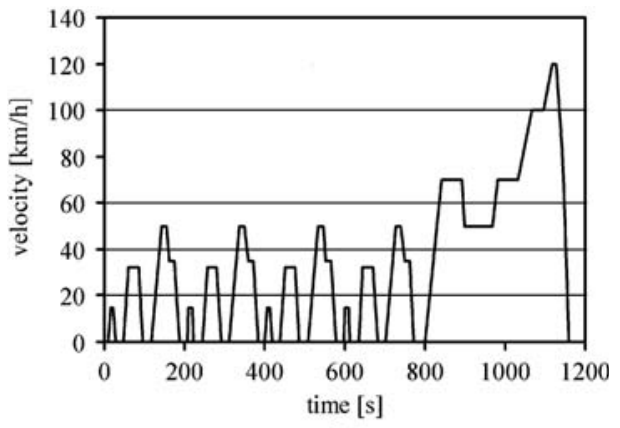

(a)

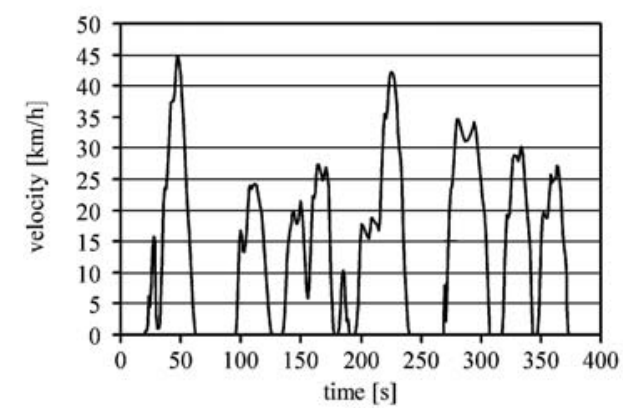

(b)

Fig. 3 Velocity profiles as used in the simulation. (a) NEDC and (b) Aachen City cycle

Figure 4 shows the distribution of the power demand (i.e. how often during the cycle a specific power is needed for the acceleration according to the cycle) for the Aachen City cycle for two different total masses of the car (corresponding to fuel cell cars with approximately $20 \mathrm{~kW}$ and approximately $100 \mathrm{~kW}$ PEM system). As can be seen, the power demand mostly lies below $10 \mathrm{~kW}$. For the $1300 \mathrm{~kg}$ car the maximum power demand during the cycle is slightly above $20 \mathrm{~kW}$, while for the $2000 \mathrm{~kg}$ car the maximum power demand is nearly $35 \mathrm{~kW}$ due to the larger mass. Following this result $20 \mathrm{~kW}$ was chosen as the minimum size of the fuel cell systems analysed in this study. The maximum size chosen was $100 \mathrm{~kW}$.

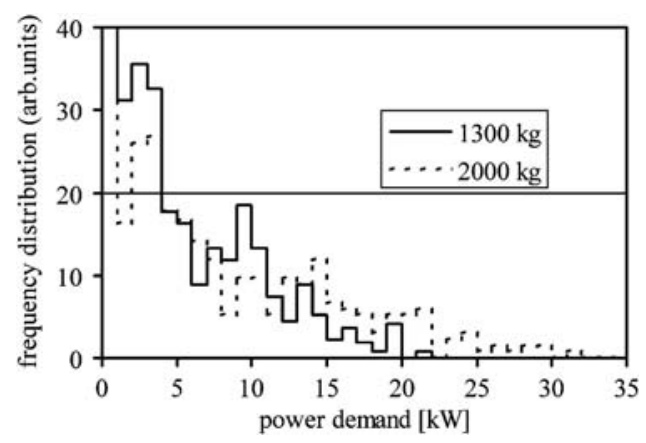

Fig. 4 Frequency distribution of the demand of electrical power for the propulsion of the vehicle in the Aachen City cycle for two assumed car masses
According to Fig. 4 these systems are strongly oversized in urban traffic, but are advantageous with respect to partial load operation. Furthermore, highpower fuel cell systems allow for higher maximum velocities in highway traffic. Consequently the range of car masses was chosen between $1200 \mathrm{~kg}$ and $2000 \mathrm{~kg}$, as given by the car mass (without fuel cell system) and the particular fuel cell system masses (see above).

The mean energy demand (expressed in fuel equivalents) for both cycles is plotted in Figs 5 and 6 . As shown, the total demand of electric energy results from the vehicle acceleration, losses due to friction, and losses due to the efficiency of the used electric motor. Furthermore, some part of the acceleration energy can be recuperated during the deceleration periods. Despite differences of up to a factor of two in the single contributions, the total energy demand in both cycles differs only slightly. As can be seen, the energy demand for acceleration (crosses) is higher in the Aachen City cycle (Fig. 6) due to the more pronounced acceleration periods and the

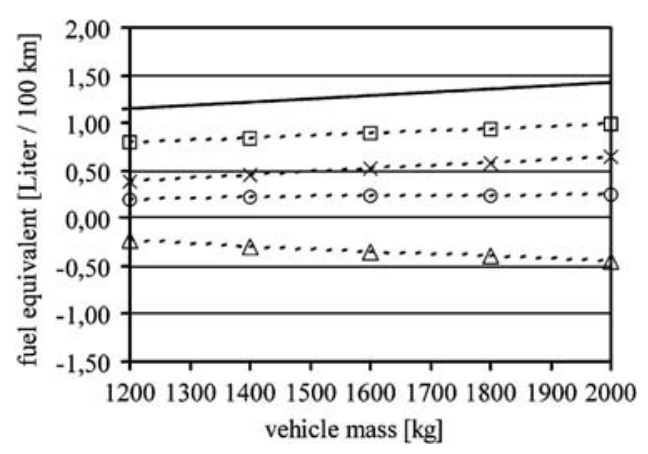

Fig. 5 Energy demand (in fuel equivalent) for the propulsion in the NEDC cycle as function of the vehicle mass. The total demand (solid lines) is the sum of four contributions (dashed lines): Acceleration of the car (cross), friction losses (square), efficiency of the electric motor (circle), and gain by recuperative breaking (triangle)

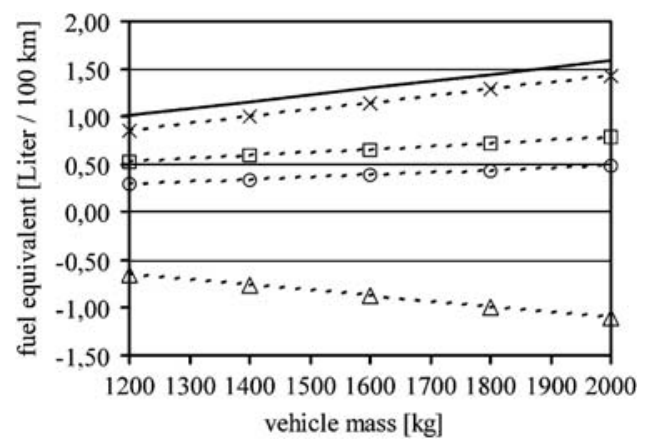

Fig. 6 Energy demand for the propulsion in the Aachen City cycle as function of the vehicle mass (according to Fig. 5) 
higher acceleration values in this cycle. In contrast, the losses due to friction (squares) are lower because of the lower mean velocity (see above). The additional energy demand due to the losses in the electric motor is nearly twice as much in the Aachen City cycle as compared with the NEDC, showing that the given motor is used close to its nominal operational value in the last cycle. Figure 7 shows the average efficiency of the electric motor for the whole driving cycle as a function of the vehicle mass.

\section{SIMULATION RESULTS}

Figure 8 shows a comparison between a PEMFC and an SOFC system, both for the pure fuel cell and the hybrid traction concept. The fuel input in the reformer is shown as a function of time for the NEDC. As can be seen, the energy (fuel) input mirrors, more or less, the power demand of the driving cycle. However, the hybrid configuration offers obvious advantages by smoothing out fuel peak demand, which can result in reducing the power of auxiliary components in addition to reduced power of the fuel cell stack. Comparing the two fuel cell types, there is a constantly lower fuel input, of the order of 20 per cent, in the case of the SOFC system mainly as a direct consequence of the better cell characteristics and the reduced system mass (see above).

As can be clearly seen in Fig. 8, the hybrid concept drastically reduces peak power demand to the fuel cell system. But as the mean power over the total cycle has to be the same for both concepts (assuming that the SOC of the battery is the same at the start and end of the cycle) this also means that the time periods with minor power demands are reduced. In other words, as discussed above, the fuel cell system in the hybrid concept is driven in the cycle at a constant, mid-range level. As the stack efficiency increases monotonically with decreasing power

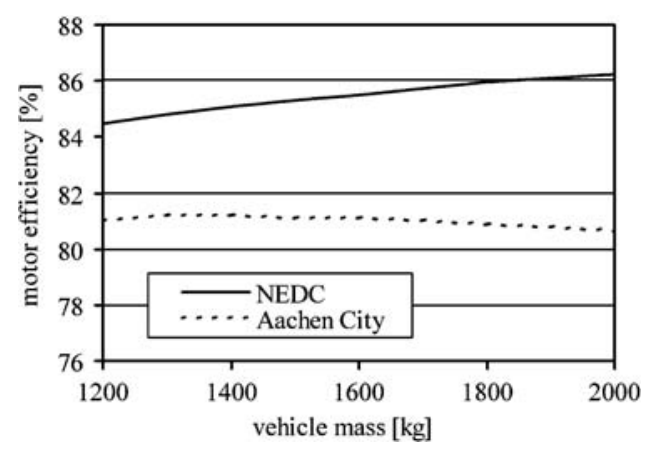

Fig. 7 Mean efficiency of the electric motor in the two given cycles

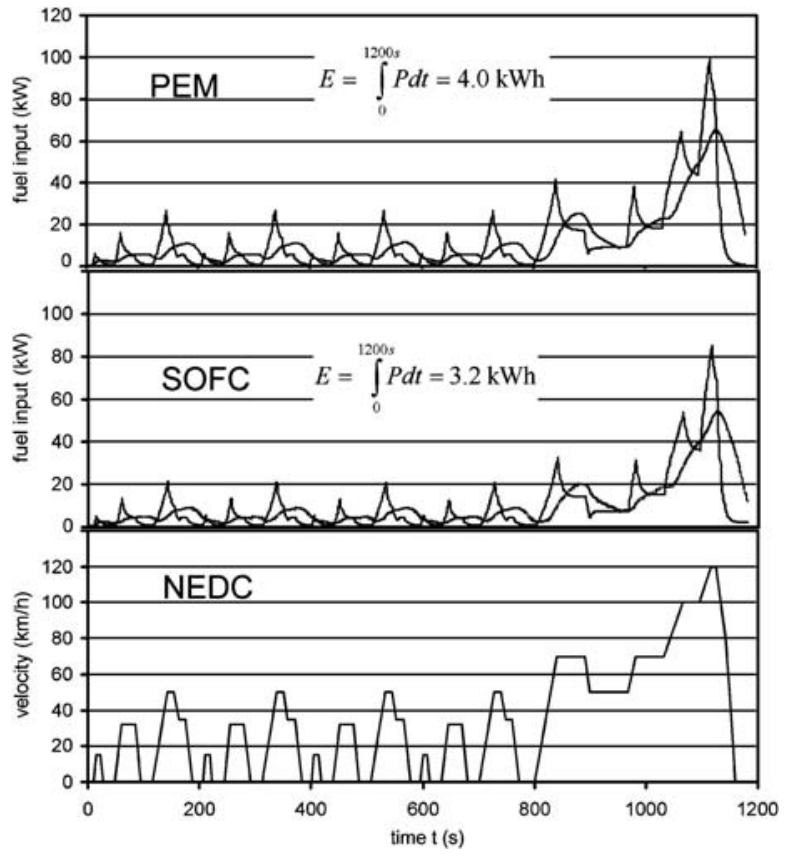

Fig. 8 (a) Actual fuel consumption for a PEM fuel cell system, (b) an SOFC system, and (c) for the NEDC. The fuel consumption is given as the lower heating value of the fuel input in the reformer, both for a fuel cell car with only a small battery (sharp peaks) and a hybrid car (smooth line)

output, it is not evident how the choice of the concept - pure fuel cell or hybrid car - affects the mean system efficiency. Figure 9 shows the comparison of the total system efficiency (fuel to electricity) in the NEDC cycle for both fuel cell types. As can be seen, the system efficiency is enhanced only in a minor way in hybrid systems as compared with pure fuel cell cars. Only for small SOFC systems does the

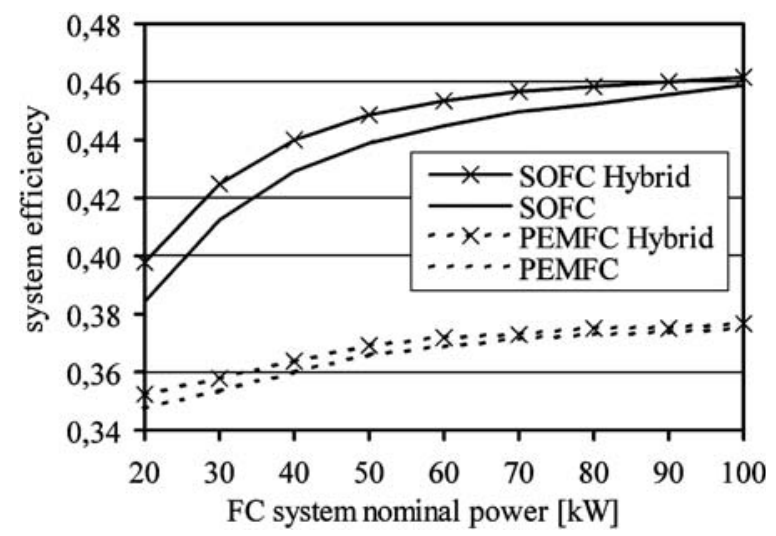

Fig. 9 Comparison of the system efficiency of PEMFC and SOFC system as function of the nominal power (defined as the power output at $750 \mathrm{mV}$ single-cell voltage) for the pure fuel cell and the hybrid traction concept (NEDC) 
additional battery lead to an increase of about 1.5 per cent in absolute system efficiency. In particular, this increase is well below the variation of system efficiency with system nominal power. This is due to the fact that in the latter case the mean value of the delivered electric power is shifted to a more pronounced partial load operation with increased system size. By applying the hybrid concept, the mean partial load operation is not affected, only the sharp power peaks are smoothed (see Fig. 8). This does not, however, strongly influence the overall system efficiency. On the contrary, as can be seen in Fig. 10 for the NEDC cycle, the resulting fuel consumption may even be higher for the hybrid systems (up to $0.1 \mathrm{l} / 100 \mathrm{~km}$ ) due to additional battery losses and, to a lesser extent, increased total weight. For the SOFC, the fuel consumption decreases with increasing nominal fuel cell power to a minimum at about $60 \mathrm{~kW}$ nominal; this is a direct consequence of the increased fuel cell system efficiency (Fig. 9). At a system power greater than $60 \mathrm{~kW}$ a significant increase of fuel consumption arises due to the larger total car mass attenuated only slightly by the increase in system efficiency.

A different behaviour can be seen in the Aachen City cycle (Fig. 11). This cycle is very dynamic and thus more sensitive to the total vehicle mass, leading to a monotonic increase in fuel consumption for the whole range of system nominal power.

In addition to system nominal power and battery size, the system efficiency and fuel consumption are influenced by a variety of other parameters. One important factor is the 'steam-to-POX' ratio in the reformer unit, which influences the reformer efficiency as steam reforming is more efficient than POX reforming. As described above the 'steamto-POX' ratio is set by a control unit to obtain an

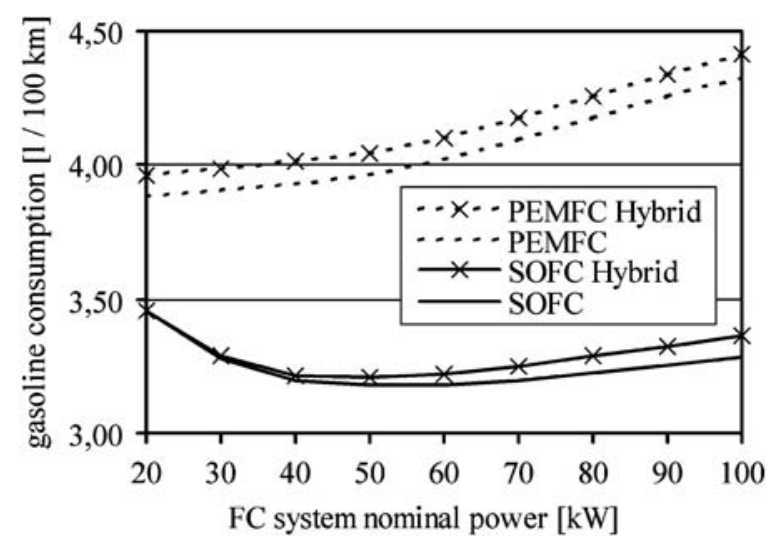

Fig. 10 Fuel consumption as a function of the fuel cell system nominal power in the NEDC cycle (fuel cell and hybrid traction concept)

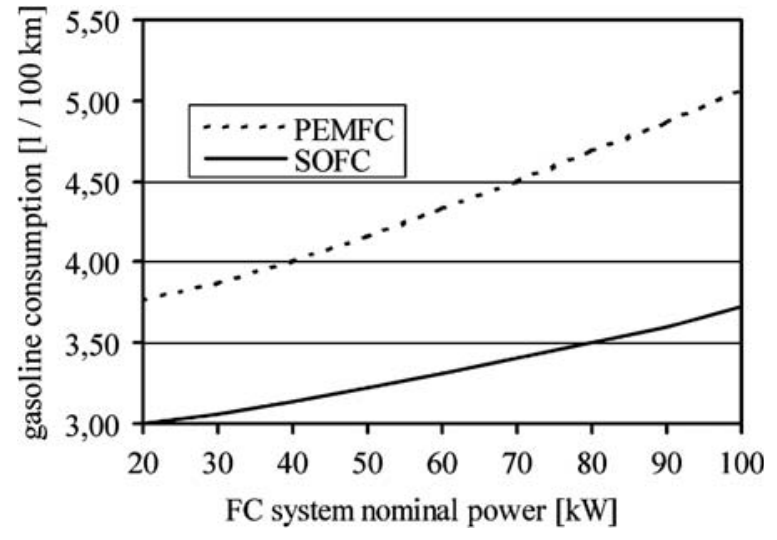

Fig. 11 Fuel consumption as a function of the fuel cell system nominal power in the Aachen City cycle

autothermal operation and therefore depends on the thermal coupling of the reformer unit to the other components and the surrounding hotbox. Increasing the parameters of the heat transfer in the simulation leads to higher system efficiency (Fig. 12) caused by an increase of the steam reforming contribution (Fig. 13).

The electrical demand of peripheral components, i.e. fans and compressors, strongly depends on system pressure, pressure drop inside stack, and reformer and auxiliary units as on the details of the used components. This electrical demand reduces the effective net power output of the systems. Figure 14 shows the influence of the assumed specific electric demand of the used blowers. As the flowrate on the cathode of the SOFC is large ( $\lambda=8$ to 20$)$ compared to the PEMFC system $(\lambda=1,5)$, the slope of the SOFC is more pronounced as in the PEM system.

As depicted in Fig. 4 the total vehicle mass strongly influences the fuel consumption. A major part of the total mass of the car is the fuel cell system itself,

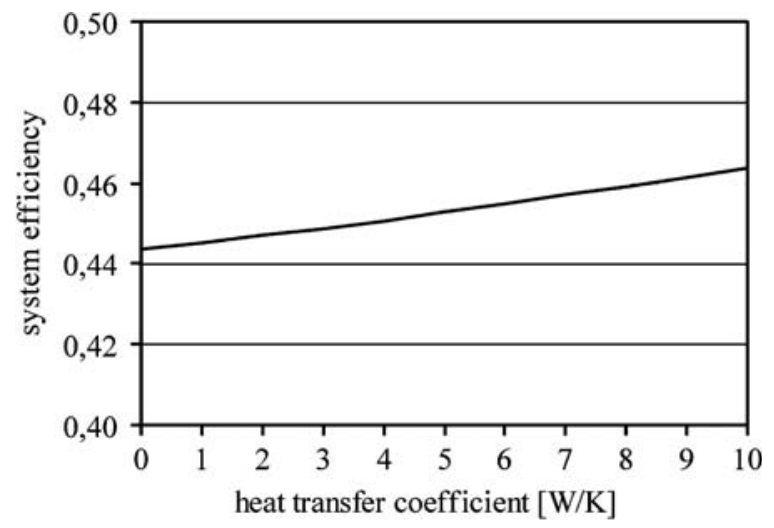

Fig. 12 SOFC-system efficiency in the NEDC as a function of heat transfer between the thermally coupled units hotbox reformer and hotbox stack 


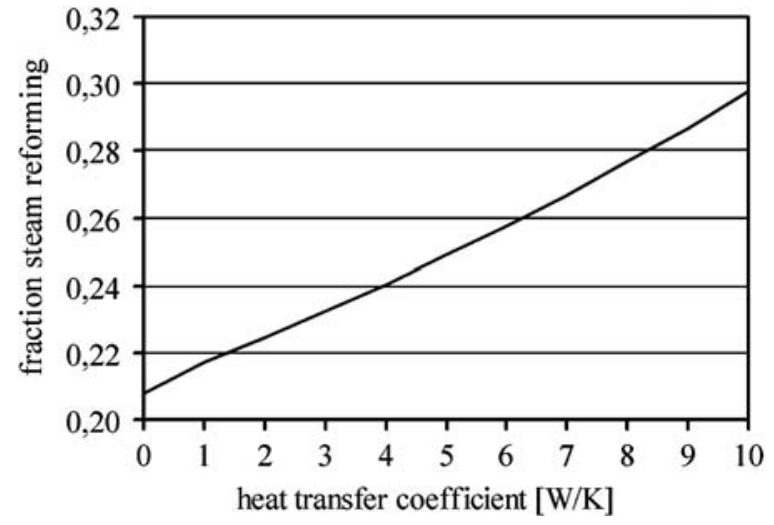

Fig. 13 Mean fraction of fuel, which is directed to the steam reforming unit by the control unit in the NEDC cycle as function of the heat transfer coefficient between the reformer and the surrounding components of the SOFC system

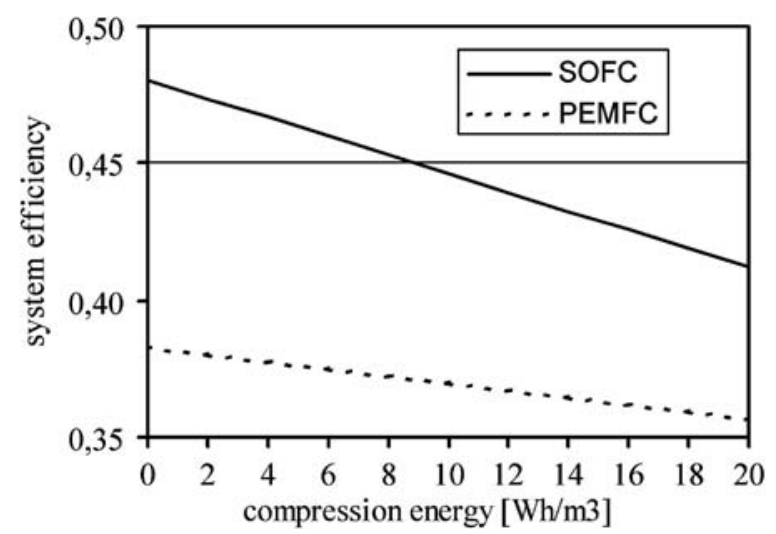

Fig. 14 System efficiency as a function of compression energy

reducing the power-specific mass of the fuel cell system notably reduces the overall fuel consumption. As suitable fuel cell systems for car traction are still in development, the real mass of a future system is not clear yet. In order to form an impression of the influence of this parameter, Fig. 15 shows the fuel consumption as function of the system mass in the range of 2 to $10 \mathrm{~kg} / \mathrm{kW}$.

As shown in Figs 9 and 10, the hybrid traction concept does not lead to a remarkable reduction in fuel consumption as the increase in fuel cell system efficiency is counteracted by an increase in the battery losses. This does not mean that the best vehicle is a car without a battery. The battery should have a minimum size sufficient to store the amount of braking energy given by the recuperation system. Figure 16 shows the effect of braking energy recuperation on the total fuel consumption. If no recuperation is possible, the fuel consumption is increased by about 10 to 20 per cent.

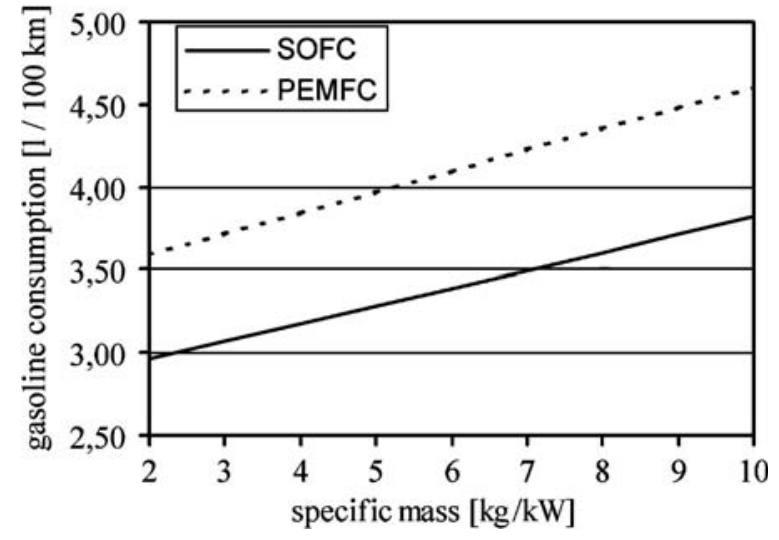

Fig. 15 Gasoline consumption of a fuel cell car as a function of the power specific mass of the fuel cell system

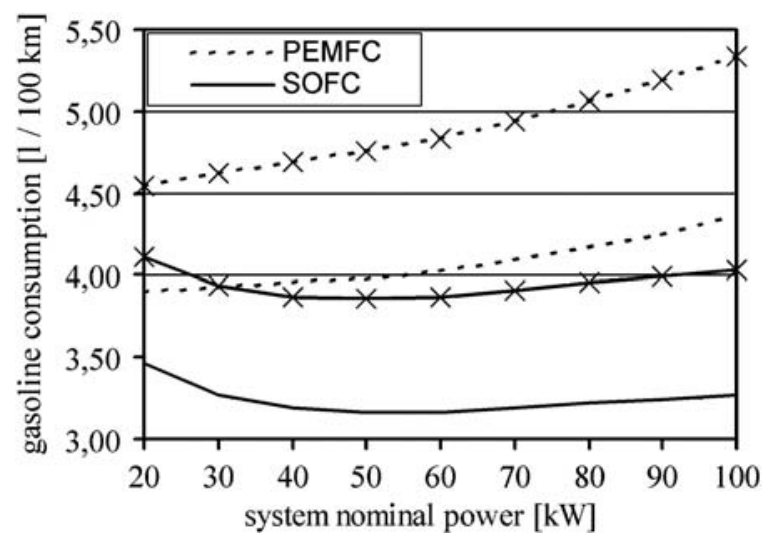

Fig. 16 Effect of the recuperation of breaking energy on the mean fuel consumption (solid lines: with recuperation; crossed lines: without recuperation)

\section{DISCUSSION AND CONCLUSIONS}

In a cooperation between the Institute for Automotive Engineering of the University of Aachen and the Bavarian Center for Applied Energy Research a simulation tool was developed to investigate the performance of different fuel cell systems in passenger cars. As fuel cell systems, an SOFC and a PEMFC system were studied - both equipped with an autothermal gasoline reformer. Therefore the currently available infrastructure can be used accepting the handicap of the increased complexity of the fuel cell system, for example due to the high temperature gasoline reformer. Alternative ways, which are not discussed in this paper, would be the use of methanol (reformable at moderate temperatures) or hydrogen as primary fuel. But since there is currently no infrastructure for either of the fuels, these systems may be preferable options for the future. In this paper gasoline-based systems have been focused on. 
Besides the calculation of the absolute values of, for example fuel consumption of a real middle-class passenger car, the simulation tool allows the study of the influence of several system parameters on system performance and thus fuel consumption by means of sensitivity studies. The calculated fuel consumption is noticeably lower than the consumption values of conventional middle-class cars with internal combustion engines. This is in agreement with measured values for the hydrogen-fuelled Daimler-Chrysler fuel cell electric vehicle NECAR 4 [8]. In this study the authors have measured for a Mercedes-Benz A-class standard vehicle equipped with a $70 \mathrm{~kW}$ PEM stack, a total car mass of $1750 \mathrm{~kg}$, a liquid hydrogen tank, and no recuperation system, a mean hydrogen consumption in the NEDC cycle of $1.1 \mathrm{~kg} \mathrm{H} \mathrm{H}_{2} / 100 \mathrm{~km}$ equivalent to (regarding heating value) 4.01 gasoline $/ 100 \mathrm{~km}$. The corresponding result of our simulation for a $70 \mathrm{~kW}$ PEMFC system (total car mass $1450 \mathrm{~kg}$ ), equipped with an autothermal reformer and braking energy recuperation, is 4.11 gasoline $/ 100 \mathrm{~km}$ (see Fig. 10). For a proper comparison this value still has to be corrected for the different car masses $(+8$ per cent, see Fig. 5$)$, the effect of the energy recuperation $(+20$ per cent, see Fig. 16), and the efficiency of the reformer and gas cleaning components (about -20 per cent). Nevertheless it gives a reasonable agreement between the simulation results and the experimental values.

In particular in city driving with frequent acceleration and deceleration periods the lowest fuel consumption can be achieved with small fuel cell systems. A more pronounced partial load operation of bigger (and thus heavier) systems only reduces overall fuel consumption in the case of less dynamic driving cycles.

Furthermore, the efficiency of the autothermal reformer unit, which directly depends on the 'steamto-air ratio', strongly influences the total system efficiency. This shows that an optimized thermal management of the whole system is crucial. An increased heat transfer from the stack and catalytic burner to the reformer leads to an increased steam reforming ratio resulting in a reduced fuel consumption. This favours the operation of an SOFC stack but, on the other hand, the high-temperature SOFC system may suffer from long start-up times or other complications not examined in this work [9].

In the hybrid traction concept the electric power demand in the acceleration periods can be taken from the battery, allowing the fuel cell to operate at an almost constant base load operation. As shown before, this does not strongly influence the overall fuel consumption, but has possible conceptual advantages not obvious in the simulation results. Smoothingout fuel peak demand results in a reduction in the power of auxiliary components in addition to reduced power of the fuel cell stack. Further, an additional battery allows the fuel cell system size to be reduced without reducing the maximum available electric power, thus potentially reducing system costs.

The simulation results show that fuel-cell-driven electric cars equipped with an on-board gasoline reformer may be a realistic concept for the near future, besides other competing technologies like, for example, the Toyota Prius II [4] (a hybrid car equipped with an internal combustion engine, an electric motor/generator, and a battery). Both systems offer obvious advantages regarding fuel consumption and thus $\mathrm{CO}_{2}$ emissions compared with conventional internal combustion engines.

\section{ACKNOWLEDGEMENT}

Financial support from the German Research Society (DFG), project no. Sti74/5-1, Sti74/5-2, Wa1112/1-1 and Wa1112/1-2 is gratefully acknowledged.

\section{REFERENCES}

1 Bossel, U. Proc. of the 3rd European Solid Oxide Fuel Cell Forum, Nantes, France, 1998, p. 55.

2 Matlab/SIMULINK 6.5, The MathWorks, Inc.

3 Braun, B., Fischer, K., Rzepka, M., Stimming, U., Biermann, J. W., Johannaber, M., and Wallentowitz, $\mathbf{H}$. Simulation code for gasoline driven fuel cell cars. Fuel cells, 2003, 3, 122-127.

4 Der neue Toyota Prius, Automobiltechnische Zeitschrift, 2001, 103(3), 184-187.

5 Der neue Toyota Prius, Automobiltechnische Zeitschrift, 2004, 106(3), 186-189.

6 Honda. http://www.hondacars.com/images/banners/ 2004/insight/insight_factsheet.pdf.

7 ADVISOR: NREL's (National Renewable Energy Laboratory) ADvanced VehIcle SimulatOR, set of model, data, and script text files for use with Matlab and Simulink.

8 Friedlmeier, G., Friedrich, J., and Panik, F. Test experiences with the daimlerchrysler fuel cell electric vehicle NECAR4. Fuel cells, 2001, 1, 92-96.

9 Holtappels, P., Lamp, P., and Stimming, U. SOFC VII, The Electrochemical Society Proc. Vol. PV, 2001, 2001-16, 265. 